\title{
Potenciális geotópok azonosítása térinformatikai módszerekkel
}

\author{
PÁL Márton - ALBERT Gáspár
}

DOI: $\underline{10.30921 / G K .73 .2021 .2 .2}$

Absztrakt: Az elmúlt évtizedekben jelentốsen megnôtt a geoturizmus és az ehhez kapcsolódó szabadidôs tevékenységek iránti igény. A földtudományok népszerúsítésének kézzelfogható elemei azok az élettelen természeti objektumok, amelyek valamilyen földtudományos, vagy akár kulturális, történelmi jelentöséggel bírnak. Ezeket geotópoknak, geohelyszíneknek nevezzük. A geotópok legtöbb esetben olyan földtani kibukkanások, amelyeket a geoturizmus eszköztárával (infrastrukturális fejlesztések, geooktatás) ruházhatunk fel a tudományos információ egyszerú, hétköznapi emberek számára is érthetó átadására. Földtani túratérkép szerkesztésekor az elsôdleges feladat, hogy azonosítsuk ezeket az objektumokat. E folyamat során különbözó alapanyagokat használtunk: geológiai és topográfiai térképeket, a világhálón megosztott Google-fotókat és a földtani alapszelvénylistát. Az elóállt adathalmazt GIS-módszerek segítségével szürtük, osztályoztuk. Munkánk célja a Bakony-Balaton UNESCO Globális Geopark Csopak környéki részérôl készült nagy méretarányú földtani túratérképen bemutatható geotópok keresése volt. Az eredmény, valamint az elkészült térképmú hatékonyan szolgálja a földtudományos örökségvédelem ügyét, felhívva a látogatók figyelmét a jelentôs földtani értéket képviselô képzôdményekre.

Abstract: Geotourism and tourism activities with geoscientific content have been more and more popular nowadays. The utilized elements of promoting geosciences are the geosites: natural objects on the surface of the Earth that have significant scientific, cultural and/or historic values and do not belong to the biosphere. These are mainly geological outcrops and geomorphological landmarks that can be used to communicate earth science in an easy, visible, and interpretable way for non-expert tourists. The dissemination is helped by the toolset of geotourism such as infrastructural developments and geoeducation. When editing a geological hiking map, the initial task is to identify these objects. During this process multiple data sources can be used: geological and topographic maps, shared Google Photos and the database of the geological key sections. Subsequently the list of potential geosites is filtered with GIS and classifying methods. The aim of our project was to find the most exciting geosites for the first large-scale geological hiking map of Hungary in the Csopak area of the Bakony-Balaton UNESCO Global Geopark. The results and the published map effectively serve the protection of geological heritage while drawing tourists' attention on the important values of the abiotic nature.

Kulcsszavak: geoturizmus, geotóp, geoturisztikai térkép, földtani túratérkép, GIS

Keywords: geotourism, geosite, geotourism map, geological hiking map, GIS

\section{Geoturizmus}

A kivételes földtani, morfológiai és táji tartalmat hordozó felszínformák vizsgálata a földtudományok számára kiemelten fontos. A legtöbb kutatás a valamilyen tudományos szempontból különleges objektumok terepi munkát követô feldolgozására épül. Egyes értékes képzôdmények lehetnek kevésbé feltúnóek, inkább csak a tudományos világ számára érdekesek. Mások azonban látványosan mutatják be a földtudományos örökség egy szeletét, ami miatt turisztikai hasznosításuk is megindult, egyúttal védelemben is részesülnek.

A természet utánozhatatlan gazdagságát a biodiverzitás (biológiai sokféleség) és a geodiverzitás (földtani-földrajzi sokféleség) elemcsoportjaira bonthatjuk. Geodiverzitás alatt a földtani, felszínalaktani, talajtani és vízrajzi képződmények és folyamatok összességét értjük (Brilha et al. 2018). A földtani-földtudományos örökség leglátványosabban megjelenô elemeit geotópoknak (geohelyszíneknek) nevezzük. Ezek a geodiverzitás magas tudományos értékkel bíró, in situ (eredeti helyükön található) elemei, amelyek a környezet leglátványosabb, legjellegzetesebb, legérdekesebb képzôdményei. Ezek lehetnek sziklafalak, barlangok, vagy egyéb érdekes földtani alakulatok, amelyeket turisztikai és földtudományos tekintetben is érdemes bemutatni. A földtörténet egy adott szegmense általuk elérhetôvé válik: betekintést nyerhetünk történetük segítségével a régmúlt eseményeibe. A földtani-földtudományos örökség kifejezés elsôsorban ezeket a tudományos és idegenforgalmi szempontból is érdekes helyszíneket, objektumokat foglalja magába, kiegészítve ezek védelmének eszközeivel (Brilha 2015, Magyarhoni Földtani Társulat 2017).

A turizmus feladata - a kulturális örökséggel való összekapcsolással mindezek bemutatása, a közvetített, olykor sokmillió éves üzenet átadása. A geoturizmus az idegenforgalom olyan fiatal ága, amely napjainkban egyre népszerúbb az egyéb szabadidôs tevékenységek és lehetôségek között. Az elmúlt évtizedek információs forradalma fölébresztette az emberekben a természet jelenségeivel kapcsolatos tudás iránti vágyat is - egyre többen látogatnak el tudományos szempontból jelentôs helyszínekre, hogy megértsék, megfejtsék Földünk titkait. Thomas Hose (1995) tette az elsố lépést a geoturizmus 
fogalomkörének elmélyítésére, majd néhány évtizedes formálódás után napjainkban Newsome-Dowling (2010) meghatározását használjuk. E szerint a geoturizmus földtudományos és táji, tájképi értékeken alapszik. Elősegíti a fontosabb geotópok népszerúsítését, segít a geodiverzitás megôrzésében, valamint a földtudományos információ értelmezésében.

Bizonyos tulajdonságok egyértelmúen megkülönböztetik a geoturizmust a turisztikai szektor többi résztvevőjétől. Egyrészt tudományos információt közvetít a geotudományos örökség bemutatásán keresztül, másrészt a bemutatott helyszínek a helyben lakók számára is informatívak és hasznosak, ugyanis a különleges jelenség és az általa hordozott tudományos-kulturális tartalom identitásuk részévé válhat. De mindezek mellett fontos a turizmus általános infrastruktúrájának jelenléte is, hiszen többnyire nem tudósok, szakértôk, hanem turisták keresik fel ezeket a helyszíneket. Számukra kell értelmezhetôvé és vonzóvá tenni a földtudományos üzenetet (Dowling 2011, Grant 2010).

A geoturizmus általában mélyebb érdeklôdést jelent a természeti és az ehhez kapcsolódó kulturális értékek iránt. A szabadidô élvezetes eltöltésén túl a környezettudatos magatartás egyaránt alapvetố egy geoturista számára. Ugyanez a szemléletnek kell kialakulnia a területen lakókban is: számukra közvetlen környezetük épsége és a létrejövő munkahelyek, egyéb anyagi javak használata egyaránt fontos (Dowling 2011).

A geoparkok a geoturizmus és a földtudományi örökségvédelem nemzeti keretek között múködố (de akár nemzetközi hálózatokhoz is kapcsolódó) intézményei (1. ábra). Az élettelen természeti képződmények védelme szervezett keretek között a legutóbbi évtizedekig nem öltött formát. Az Európai Geoparkhálózat (European Geoparks Network EGN) és a Globális Geoparkhálózat (Global Geoparks Network - GGN) megalapításával a tudománynépszerúsítési szempontok mellett a természetvédelem is elôtérbe került. A geoparkok bárki számára látogathatók, elsôdleges céljuk, hogy a természeti örökség és információ szélesebb körben jusson el az emberekhez. Fontos hangsúlyozni, hogy emellett a kulturális, történelmi, ökológiai és oktatási értékek közti összhangra is törekednek, ezáltal minden látogató találhat érdeklôdésének megfelelô tematikájú helyszínt (Bakony-Balaton Geopark 2012).

Munkánk a geodiverzitás és a geoturizmus „csomópontjainak”, azaz a geotópok azonosítására irányul a Bakony-Balaton UNESCO Globális Geopark Csopak környéki területén. A helyszínek összegyújtésével és elemzésével célunk, hogy földtudományos szempontú támpontokat adjunk a Geoparknak és a döntéshozóknak, hogy megalapozhassák jövőbeli munkájukat és fejlesztéseiket. Az elemzés egy olyan kartográfiai és térinformatikai eszközöket tartalmazó munkafolyamat, amely reprodukálhatósága révén más területen is jól alkalmazható. Eredményeinket egy kartográfiai szempontból újdonságnak számító nagy méretarányú földtani túratérképen ábrázoltuk (Albert et al. 2018).

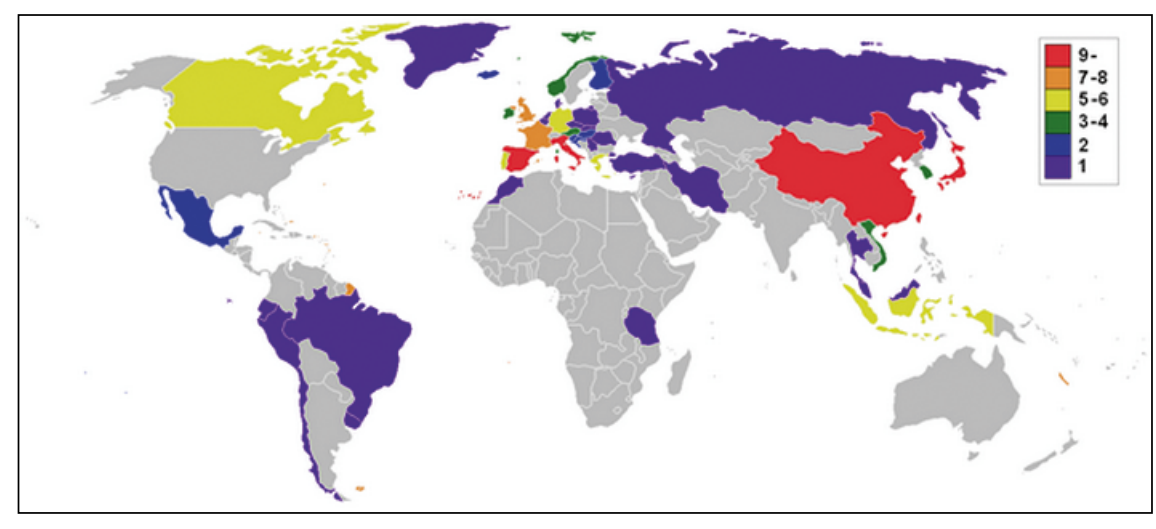

1. ábra. A Globális Geoparkhálózat tagjainak száma országonként, 2021-ben

\section{A mintaterület bemutatása}

Vizsgált területünk a Balaton-felvidék Balatonalmádi és Balatonfüred közötti területén helyezkedik el. Kiterjedését a „Csopak és környéke geotúratérképe" c. kiadvány (Albert et al. 2018) kivágata határozza meg: északnyugaton Hidegkút és Veszprémfajsz, délen pedig a Balaton határolja (2. ábra). Napjaink egyik legnépszerúbb hazai turistacélpontja a Balaton-felvidék, mely nem csak strandjairól, borairól, hanem gazdag természeti látnivalóiról, tájképi sokféleségérôl is híres. Mediterrán jellegú éghajlata miatt alkalmas szôlőtermesztésre, azonban a meredek völgyek között futó sédek nyaranta is kellemesen hûvös hômérsékletet biztosítanak. Az ember környezetformáló szerepe itt is megjelenik: tevékeny erdôgazdálkodás során tartja karban a karsztbokorerdóket és tölgyeseket, valamint egyre nagyobb hangsúly helyezôdik a fokozottan védett feketefenyvesek megóvására (Bakonyerdố Zrt. 2017).

A Dunántúli-középhegység legidősebb kôzetei a Balaton-felvidéken bukkannak fel. A Pelsoi egység paleozoós és mezozoós képzódményei a késố mezozoikum során lejátszódott tektonikus mozgások hatására meggyưrôdtek, és egy óriási szinklinálist alkotnak, amelynek tengelyében a legfiatalabb, a szárnyak felé pedig az idôsebb kôzetek fordulnak elô. A kompresszió hatására ezeken a területeken az áttolódások révén az idôsebb képzôdmények a felsô triász rétegekre tolódtak. Szép példa erre a Balaton-felvidék keleti részén található régóta ismert Litéri-feltolódás (Teleki 1939, Erdélyi Fazekas 1943, Budai et al. 1999). Gyưrt, takarós variszkuszi aljzat képezi a legalsó szerkezeti emeletet (488-359 M év). A Balaton-felvidék keleti része rétegsorának legidősebb részét aleurolitpala és agyagpala (Lovasi Agyagpala) alkotja, amelyek rétegei közé savanyú, vagy bázikus vulkáni kôzetek ékelôdtek (amelyek alacsony fokú metamorfózist szenvedtek). Ilyen az Alsóörsi Metariolit: a tengeri üledék közé rétegződött vulkanoklasztit átkristályosodott alapanyagának 


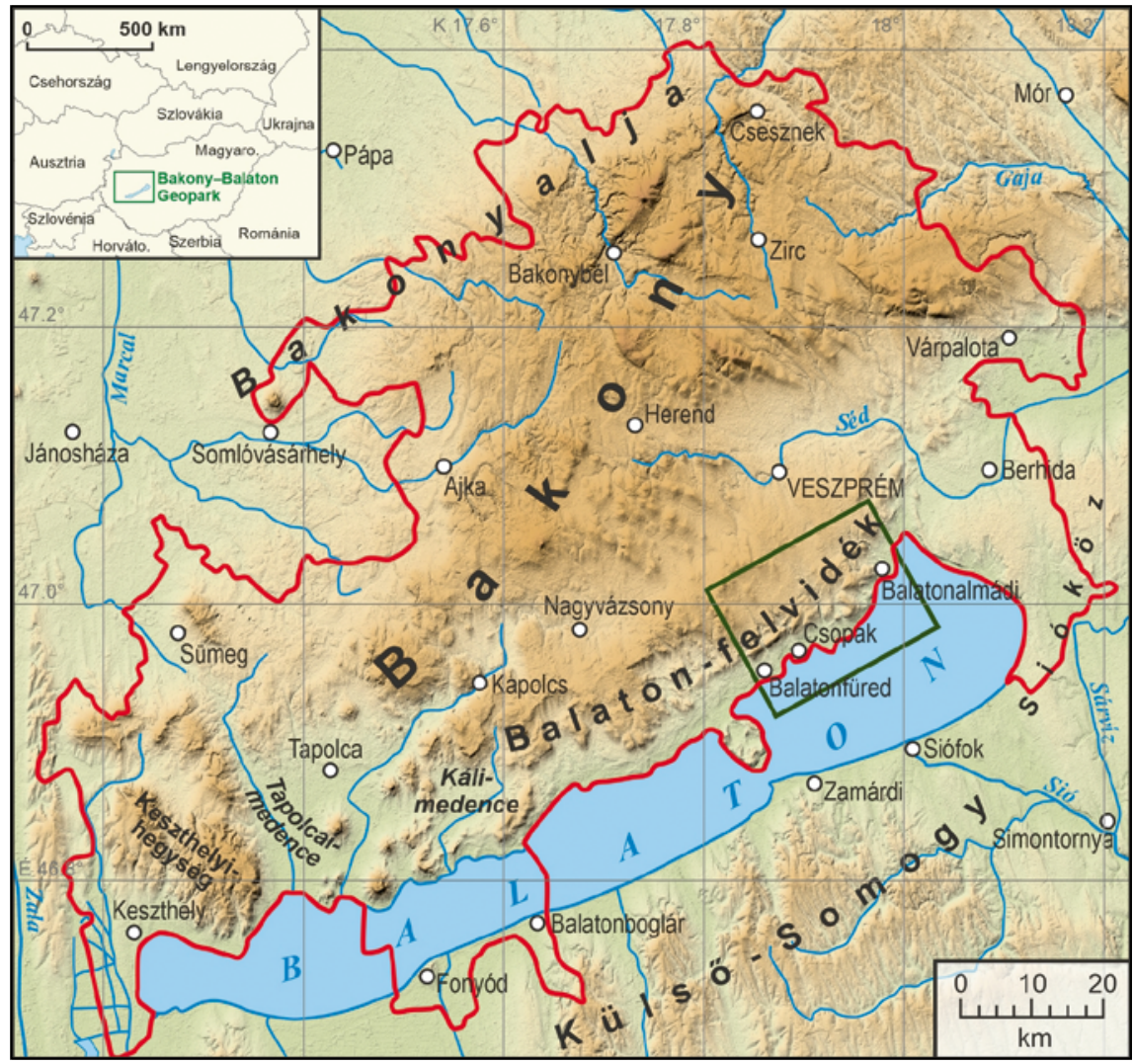

2. ábra. A Bakony-Balaton UNESCO Globális Geopark területe (piros vonal) és a vizsgált terület (zöld téglalap)

uralkodó ásványai a kvarc, földpát és biotit (Fülöp 1990). Felszíni elterjedésük igen korlátozott: szép feltárást Lovasi Agyagpalából egyáltalán nem, Alsóörsi Metariolitból csak egykét helyen találhatunk.

Az idôs, paleozoikumi kôzeteket fedố felsô szerkezeti emeletet kettéoszthatjuk a területet leginkább meghatározó permotriász, illetve az ettôl fiatalabb képződményekre. Jelentôs vastagságú üledék rakódott le a permben, amikor a Balaton-felvidék akkori területeire regionális süllyedési szakasz volt jellemzó. A 200-800 m vastag Balaton-felvidéki Homokkó ( 280-251 M év) alsó részét konglomerátum, a felsốt pedig homokkô és iszapkó (aleurolit) váltakozása adja, amelyre rátelepülnek az alsó triász kôzetek (Fülöp 1990).

A korai triászban (250-240 M év) történt tengerszint-emelkedés hatására kialakult sekélytengeri rámpa miatt a triász közepéig sziliciklasztos és karbonátos üledékképzôdés történt (Budai et al. 1999). Az Arácsi Márga selflagúnában, míg a Werfeni Formációcsoport a part menti területek lepusztulása révén alakult ki.
A maradék selftengerben Csopaki Márga képzôdött. A középsố triászban (240-230 M év) Aszófói Dolomit képzôdött. Erre a gipszes-kalcitos üledékre települt az Iszkahegyi Mészkố (mésziszap). Az alsó triászban elkezdôdött karbonátrámpa-fejlôdés a Megyehegyi Dolomit kialakulásával zárult, majd ez a rámpa nem sokkal később szétdarabolódott. A kialakult medencéket a helyenként ôsmaradványokban gazdag Felsôörsi Mészkô jellemzi. Kisebb vulkáni múködés (tûzgumós Nemesvámosi Mészkô) és medencefeltöltés (Budaörsi Dolomit) zajlott még az idôszakban. A felsô triászban (230-210 M év) a medencék teljesen feltöltôdtek (Füredi Mészkő, Veszprémi Márga), illetve a korábban kiemelkedett platformok tovább gyarapodtak (Edericsi Mészkó). A Sándorhegyi Mészkô és a Fôdolomit képzôdése zárta a triászt, szárazabb klímát jelezve (Budai-Konrád 2011).

Területünkön a neogén képződmények alárendeltek a paleo-mezozoós kôzetekhez képest. Kerekített kavics, konglomerátum vagy breccsa alkotja a pannon Diási Formációt. Ennek fedôi, a Somlói és Tihanyi Formáció, amelyek sekély selfi területen képzôdtek. A legelterjedtebb az édesvízi Nagyvázsonyi Mészkő, amely Szentkirályszabadja és Vörösberény környékén bukkan legnagyobb mértékben felszínre (Budai et al. 1999).

A mintaterület földtudományos különlegessége a variszkuszi és alpi folyamatok összefonódásából adódik. A földtörténeti események nyomán kialakult jellegzetes felszínformák, kibukkanó földtani feltárások és klimatikus sajátosságok teszik mind tudományos, mind idegenforgalmi szempontból érdekessé a Balatonfelvidék keleti részét.

\section{Geoturisztikai térképek - kapcsolat a geoturizmus és a kartográfia között}

A geológiai és turistatérképek hagyományosan a topográfiai térképekből gyökereznek. Mindkét típus sajátos céljai szerint alakította, egészítette ki a topográfiai jelkulcsot: míg a turistatérképeken a terepi tájékozódás, addig a földtani lapokon a tudományos információ közlése az elsôdleges. Napjainkra azonban megjelent az igény a terepi használatra is alkalmas, de földtani-geomorfológiai adatokat, érdekességeket is tartalmazó térképek iránt. A geoturisztikai térképek tudományos és ismeretterjesztô tulajdonságait és lehetôségeit több szerzô is tárgyalja (pl.: Albert 2004, Martin 2010, Regolini-Bissig 2010). Magyarország első nagy méretarányú földtani túratérképe 2018-ban jelent meg (Albert et al. 2018). A geotópok azonosításának ismérveit és szempontjait e térkép példáján mutatjuk be.

A geoturisztikai térképek ötvözik a hagyományos turistatérképek és a földtani-geomorfológiai térképek tulajdonságait. Jelkulcsuk emiatt bonyolult, sokféle elemet tartalmaz: nagyjából az elemek fele a topográfiai (pl. domborzatrajz, vízrajz, földrajzi nevek), másik fele a földtudományos tematikus térképekbôl származtatott. Ezek kombinálásával válik alkalmassá a térkép a terepi tájékozódásra és a tudományos adatközlésre (Albert 2004). 
Geoturisztikai célokra nagy és közepes méretarányú térképek egyaránt alkalmasak. Míg az 1:5000 - 1:50 000 térképek elsôsorban terepi tájékozódásra készülnek a földtani érdekességek környezetének részletes bemutatásával, addig az 1:50 000 - 1:500 000 térképek fố célja, hogy áttekintést adjanak egy területrôl, bemutatva a fontosabb geotópokat, megközelíthetôséget és a fố turisztikai infrastruktúrát. A térképek szerkesztési folyamata is összefüggésben van a méretaránynyal. A kis és közepes méretarányú múveket legtöbbször levezethetjük már létezô kartográfiai termékekbôl, míg a nagy méretarányú térképek friss adatfelvételt igényelnek. A geohelyszínek megfelelő azonosítása rendkívül fontos, hiszen ezek a térkép legfontosabb elemei: ezek hordozzák azt a látható földtudományos értéket, ami miatt magát a térképet szerkesztjük (Reynard et al. 2009).

\section{Adatgyújtés és az adatbázis körvonalai}

A térinformatikai elemzés és a GISeszközökkel történô geohelyszínkeresés fố célja, hogy megtaláljuk a mintaterület földtani, felszínalaktani, vízrajzi és táji szempontból legjelentôsebb és turisztikailag leginkább hasznosítható látványosságait. A potenciális geotópok kijelöléséhez többféle topográfiai és földtani tartalmú adatforrást vizsgáltunk. Átnéztük az 1:25 000 méretarányú katonai GaussKrüger és az 1:10 000 méretarányú polgári EOTR topográfiai térképlapokat, valamint a Balaton környékének építésföldtani (1:20 000) és a Balaton-felvidék földtani térképét (1:50 000). Mivel ezek az adatforrások már több évtizedesek, pontosabb információra is szükségünk volt, hogy naprakész adatbázist készíthessünk. Elsố lépésben szûrtük a területet a beépítettségpoligonokkal (amik az elmúlt évtizedekben jelentôsen nôttek), valamint a bányászati területekkel (amiken nem folytatható turisztikai tevékenység). A további pontosítás érdekében a Magyar Bányászati és Földtani Szolgálat (MBFSZ) alapszelvény-adatbázisát és a Google-on elérhető felhasználói fényképeket használtuk. Az adatbázis szerkesztését, a GIS-elemzéseket, valamint a megjelenítést a QGIS szabadfelhasználású térinformatikai szoftverben végeztük.

\section{Topográfiai térképek}

A 20. század második felének magyar katonai topográfiai térképei a nemzetközi szelvénybeosztású, GaussKrüger-vetületú és szovjet mintájú jelkulcsot alkalmazó térképrendszerek elveit követve készültek. Az 1:25 000 méretarányú lapok alapjai az 1968-1982 között az akkori 1:10 000 méretarányú térképek felhasználásával, légi fényképek és terepi bejárás alapján készített, helyesbített térképek. A polgári szektor térképhasználata a térképek titkossága miatt 1992ig korlátozott volt. Az elsố munka az 1957 utáni „népgazdasági célú” felmérés volt, amely 1:10 000 méretarányban 4098 szelvénnyel fedte le az országot. A szovjet nyomásra történt vetület- és szelvényezésváltás után (1975) kezdốdött az 1952-1980

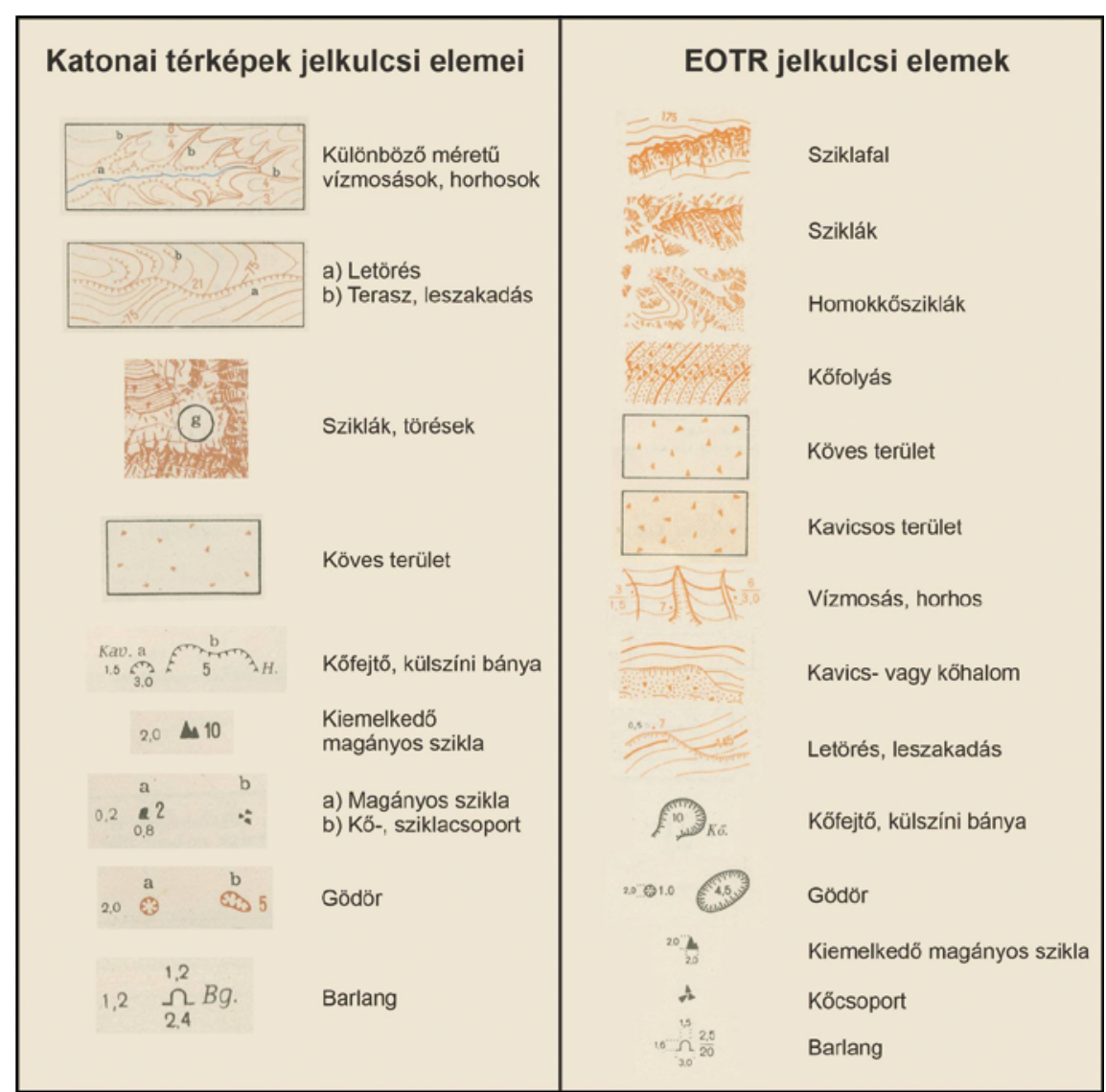

3. ábra. Az adatbázisban pontszerú elemként rögzített jelkulcsi kategóriák. Részletek a Gauss-Krüger katonai (MNTI 1964, balra) és az EOTR (MÉM OFTH 1977, jobbra) polgári topográfiai térképi jelkulcsokból.

közötti térképezésen alapuló EOTRfelmérés, amely napjainkig is a polgári kataszteri és topográfiai térképek rendszere az Egységes Országos Vetülettel (EOV) (Zentai 2015). Magyarországon jellemzóen ezeket az 1:10 000 méretarányú topográfiai térképeket használják a geológusok a nagyobb területet lefedố geológiai térképezési munkálatokhoz (Albert 2019).

Munkánk során mindkét rendszer 1:10 000 méretarányú topográfiai térképeit vizsgáltuk. Kijelöltük a mintaterületre vonatkozó térképlapokat, majd a szkennelt állományokat georeferáltuk, és a projekt adatstruktúrájának kialakításával térinformatikai környezetbe helyeztük. Ezután az összes térképi jelet (MNTI 1964, MÉM OFTH 1977), amely geotópot takarhat, megjelöltük, és pontszerú elemként felvettük a QGIS megfelelő attribútumtáblájába. A 3. ábrán láthatók mindkét rendszerből azok a jelkulcsi elemek, amelyeknek megfelelô tereptárgyak vagy domborzati formák helyet kaptak az adatbázisunkban.

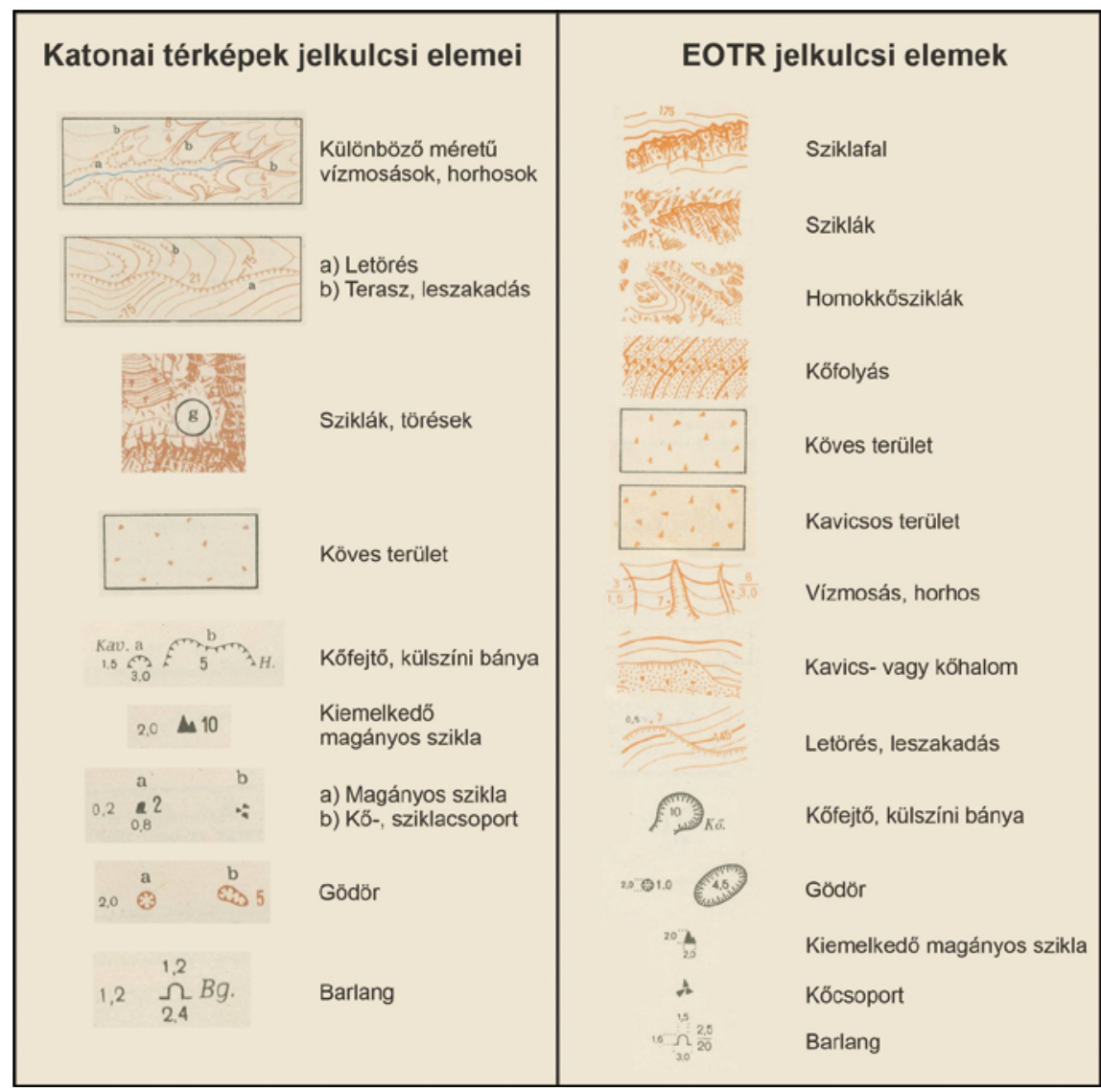




\section{Földtani térképek}

A Balaton környékének építésföldtani térképsorozata (1:20 000, 1986) az MBFSZ Országos Földtani és Geofizikai Szakkönyvtárában vizsgálható. Nagy méretarányának köszönhetôen sok kôzetkibukkanás, fúráspont, bánya, kôfejtố és kutatóárok azonosítható rajta. A jelzett elemeket a topográfiai térképekról átvettekhez hasonlóan szintén pontszerú elemként rögzítettük az adatbázisban. A késôbbi munkát megkönynyítve három különbözố terepi méretkategóriában vettük fel ôket: $50 \mathrm{~m}, 50-100 \mathrm{~m}, 150 \mathrm{~m}$. A szúrési munkafolyamat ezzel a kategorizálással egyszerúsíthetô.

A Balaton-felvidék földtani térképét (1:50 000) georeferálás után kisebb méretaránya miatt - a más forrásokból beemelt kibukkanások litológiai ellenốrzéséhez használtuk. A földtani jelkulcs hasonló elemeinek összevonásával, valamint más digitális térképi források (pl. MBFSZ online térképei) használatával létrehoztunk egy könnyebben olvasható, „turistabarát” jelkulcsot, ami összhangban és egyensúlyban van a geoturisztikai térképek többi elemével. A földtani térképekrôl leolvasható 95 képzôdménytípust 29 kategóriává vontuk össze (4. ábra). Az egyszerúsítésnél elsôdleges szempont volt, hogy a tudományos információ a legkevésbé csorbuljon. Az összevont földtani kategóriákat digitalizáltuk, ezáltal elóállt egy földtani alap a geotúratérképhez.

\section{A GIS szerepe a geoturisztikai értékelés során}

A geoturisztikai értékelés fó célja, hogy megállapítsuk egy földtudományi szempontból is látványos objektum geoturisztikai potenciálját. Ez az objektív módon, több különbözô tulajdonság figyelembevételével elôállt szám jellemzi az egyes geotópokat infrastrukturális ellátottság, jelenlegi kihasználtság és jövőbeli fejleszthetôség szempontjából (Lai-Graefe 2000, Melián-González-GarciaFalcón 2003). Az általunk használt

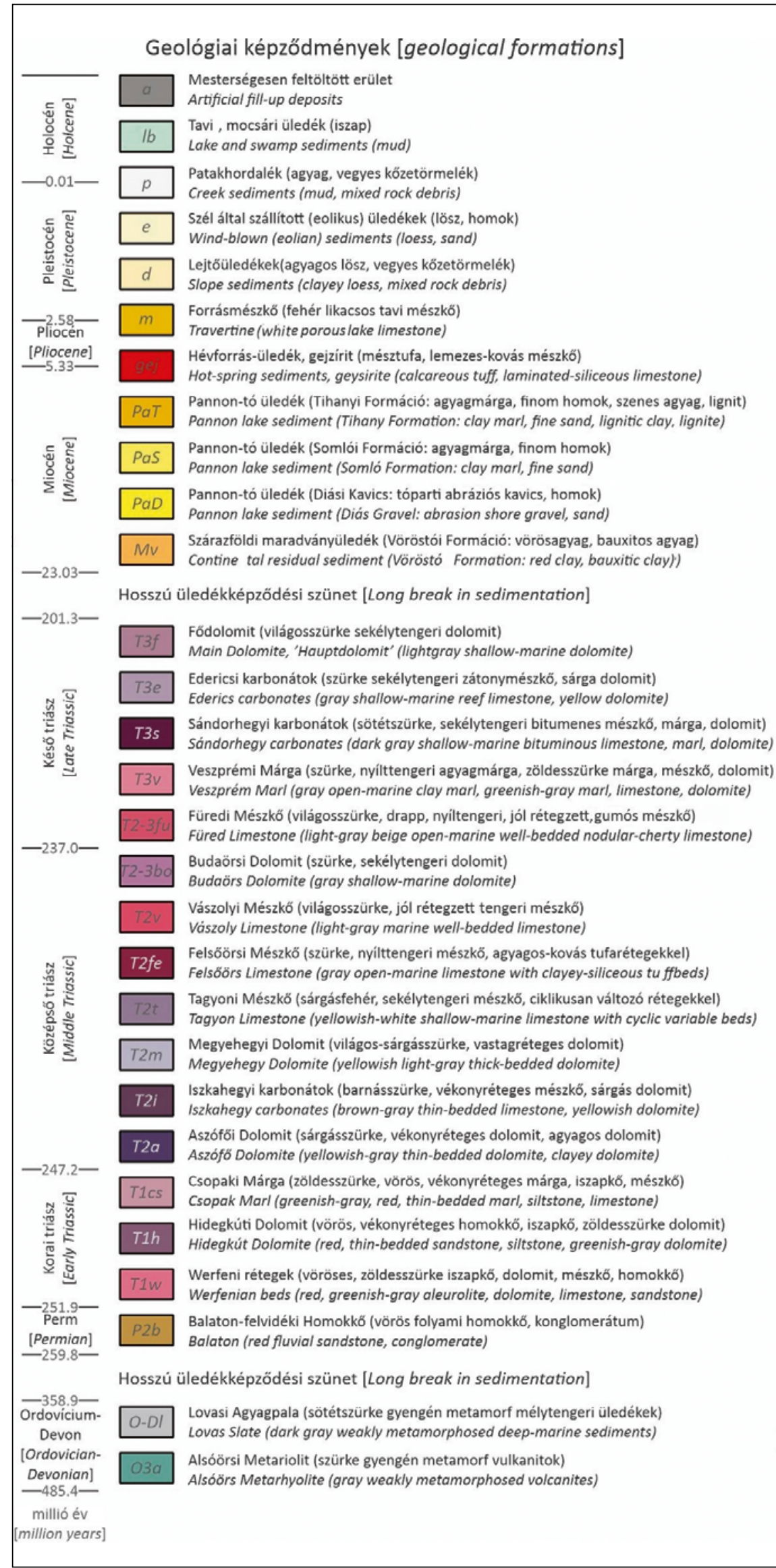

4. ábra. A földtani térképek jelkulcsát egyszerûsítve (jellemzốn a hasonló tulajdonságokkal bíró képzôdményeket összevonva) elöállt földtani jelkulcs, mely keletkezésük idôrendi sorrendjében mutatja be az egyes képzódményeket (részlet, Albert et al. 2018). 
kvantitatív értékelési modellek (Geosite Assessment Model - GAM és Modified Geosite Assessment Model - M-GAM) tudományos-oktatási, infrastrukturális és turisztikai indikátorokat használva értékelik az egyes helyszíneket. Ennek révén következtetések vonhatók le a jelenlegi hasznosítás helyességét és szükséges jövôbeli fejlesztéseket illetôen (Vujičić et al. 2011, Tomić-Božić 2014).

Az indikátorok pontozása többféleképpen történhet. A tudományos jellegû́eket többnyire szakértôk bevonásával, míg a többit terepi bejárás és tapasztalatszerzés segítségével, illetve GIS-eszközökkel értékelhetjük. A következókben az utóbbi indikátorok megállapítása során alkalmazott módszereket mutatjuk be.

\section{Szúrés}

Az adatrögzítés során több száz pontszerú objektumot vittünk fel az adatbázisba. A tervezett megjelenítés méretarányában nehézségekbe ütközik a térképi ábrázolásuk, valamint ezek jó része nem is rendelkezik turisztikai és/vagy földtudományi szempontból jelentôs értékkel. Különbözố szúrési módszereket alkalmaztunk annak érdekében, hogy a ma is létezô, legjelentôsebb helyszínek halmazát kapjuk eredményül.

Figyelembe kellett vennünk, hogy a beépítettség - fóleg a rekreációs övezetekben - nagymértékben nôtt az elmúlt évtizedek során. Az OpenStreetMap adatbázisából kiemelt település- és ipartelep-poligonokkal kiszúrtük a valószínúleg megsemmisült kibukkanásokat, valamint a bányakataszterrel a nem

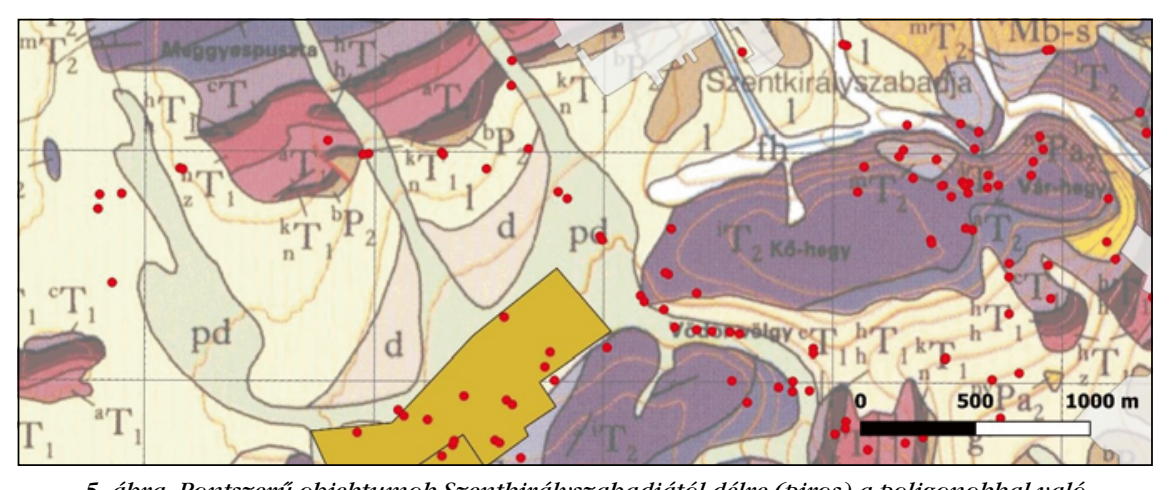

5. ábra. Pontszerú objektumok Szentkirályszabadjától délre (piros) a poligonokkal való szürés elôtt. Szürkék a beépítettséget, sárgák a bányaterületet jelzô poligonok

látogatható és engedéllyel rendelkezô bányákat (5. ábra). Ezt azonban muszáj pontosítani, mert a mintaterületen is találunk olyan értékeket (pl. volt bányaudvarokat) beépített területen, amelyet lakott területhez közel esố helyzetük miatt turisztikai célokra alkalmasak. Ehhez a pontosításhoz az MBFSZ földtani alapszelvénylistáját használtuk, amely részletesen, fotókkal is bemutatja az adott képzôdményt.

Kisebb mértékú módosítással járt a Google-fotók vizsgálata. A felhasználók a túráik során készült fényképeket (pl. sziklafalakról, érdekesebb kibukkanásokról, barlangokról) feltöltik a Google adatbázisába, amely többé-kevésbé koordinátahelyesen elhelyezi ezeket a Google-térképen, illetve a Google Earth szoftverben. Ezek segítségével néhány, turisták által gyakrabban látogatott helyszín is bekerült az adatbázisba.

\section{GIS-értékelés}

Az értékelés során használt modellek (GAM és M-GAM) indikátorai közül a legtöbbet vonzáskörzetek segítségével lehet értékelni ( 6 . ábra). Vonzáskörzet alatt az egyes potenciális geotópokat valamilyen tûréshatárral körülvevố térrészt (esetünkben az értékelési modell által megadott sugarú köröket) értjük. Így könnyen megállapítható, hogy egy adott helyszíntôl légvonalban milyen egyéb elemek (pl. épített infrastruktúra) találhatók adott távolságban. A GISeszközök segítségével egy megadott zónán belül található objektumokat térbeli lekérdezéssel tudunk kigyújteni. Az ilyen módon számszerúsített indikátorok a következők:

ETA ES KARTOGRA AIA
- Ritkaság, környékbeli elófordulás: Milyen gyakori az adott kôzettípus, formáció?

Gyakori; regionális; országos; nemzetközi; egyedüli elófordulás.

- Rálátási pontok a geotópra: Gyalogúton elérhetô „kilátópontok", nézôpontok száma, amelyekrôl különbözô látószögekbốl látható az adott terület (max. $1 \mathrm{~km}-\mathrm{re}$ ).

Nincs; 1; 2-3; 4-6; 6-nál több.

- Környékbeli természeti értékek: Egyéb természeti értékek száma $5 \mathrm{~km}$-en belül (getópokat beleértve).

Nincs; 1; 2-3; 4-6; 6-nál több.

- Környékbeli épített (történeti) értékek: Egyéb antropogén (épített, történeti) érték $5 \mathrm{~km}$-en belül.

Nincs; 1; 2-3; 4-6; 6-nál több.

- Potenciális látogatók lakóhelyének közelsége.

Több, mint $100 \mathrm{~km} ; 100-50 \mathrm{~km}$; 50-25 km; 25-5 km; kevesebb, mint $5 \mathrm{~km}$.

- Utak közelsége: Utak közelsége 20 km-en belül.

Nincs; helyi; regionális; országos; nemzetközi.

- Elérthetố pontszerú közlekedési infrastruktúra: Parkolókkal, benzinkutakkal, szerelőkkel stb. való ellátottság $2 \mathrm{~km}$-en belül.

Nincs; alacsony; közepes; magas; kiváló.

- Látogatóközpont közelsége: Látogatóközpont közelsége a geotóphoz.

Több, mint $50 \mathrm{~km} ; 50-20 \mathrm{~km}$; 20-5 km; 5-1 km; kevesebb, mint $1 \mathrm{~km}$.

- Turisztikai infrastruktúra: Turisztikai infrastruktúra szintje (gyalogutak, pihenóhelyek, kukák, mosdók stb.) $2 \mathrm{~km}$-en belül.

Nincs; alacsony; közepes; magas; kiváló.

- Szállás közelsége: Szálláslehetôség közelsége a geotóphoz.

Több, mint $50 \mathrm{~km} ; 50-25 \mathrm{~km}$; 25-10 km; 10-5 km; kevesebb, mint $5 \mathrm{~km}$.

- Étkezési lehetôség közelsége: Étkezési lehetôség közelsége a geotóphoz.

Több, mint $25 \mathrm{~km} ; 25-10 \mathrm{~km}$; 10-5 km; 5-1 km; kevesebb, mint $1 \mathrm{~km}$. 


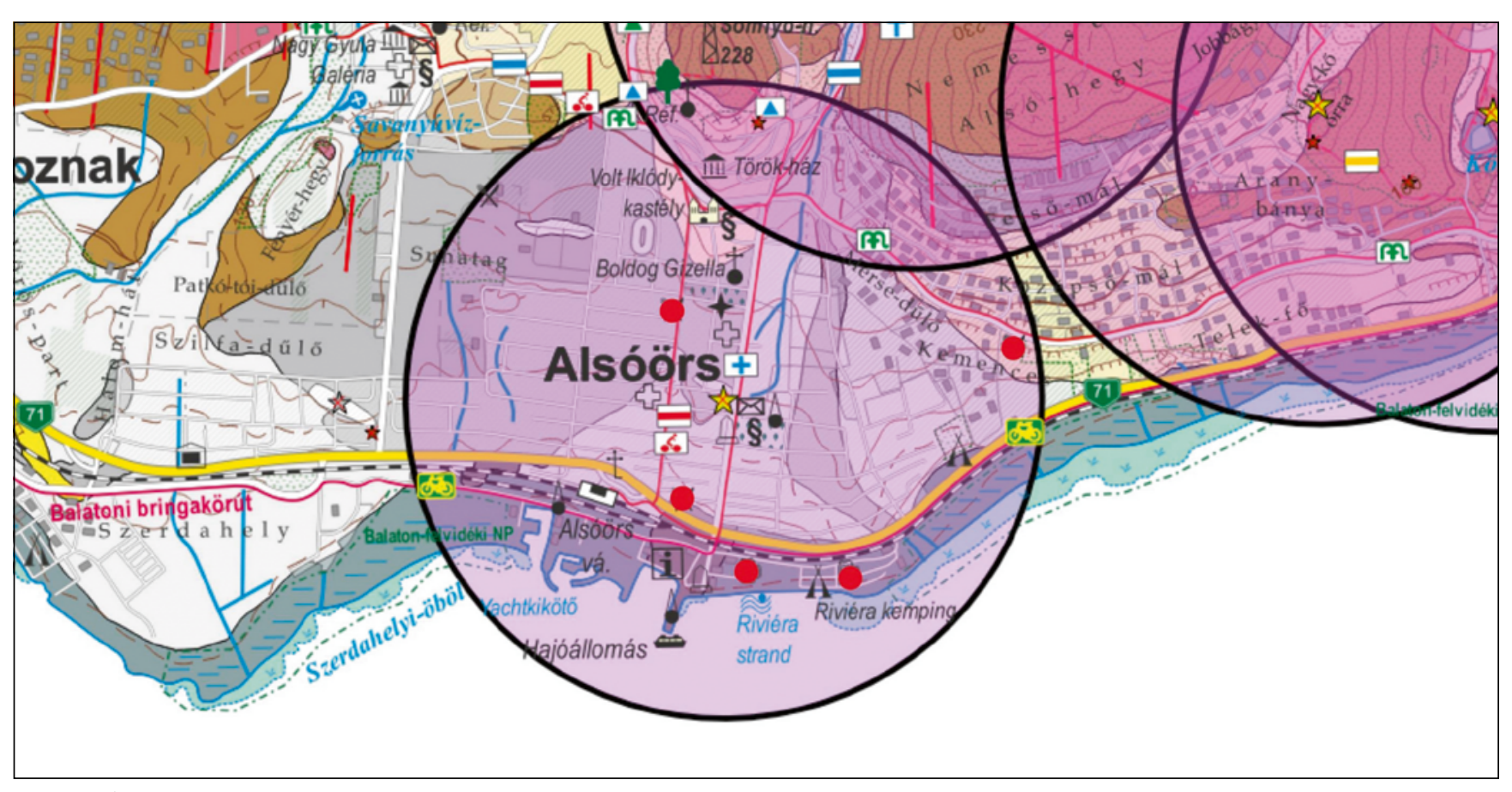

6. ábra. Az Alsóörsi Metariolit földtani alapszelvényét körülvevố 1 km-es vonzáskörzeten belül lévố étkezési lehetốségek (piros pöttyel). A geotóp erre az indikátorra a legmagasabb pontszámot kapta (az 1 km-en belül elérhetô lehetöségek miatt).

Minden helyszínt ötfokozatú skálán $(0,0,25,0,5,0,75,1)$ értékelünk. Az értékelési lehetôségek dőlt betûvel láthatók a leírások mellett.

\section{Térbeli lekérdezések}

Az adatok térbelisége, térinformatikai környezetben való alkalmazásuk nagy segítség az értékelő munka során. A „Ritkaság, környékbeli elófordulás" indikátor esetén a potenciális geotópok litológiai attribútuma, valamint a digitalizált földtani térkép poligonjai alapján lekérdezhetô, hogy hol található még meg az adott formáció, van-e még másik ahhoz kapcsolódó pontszerú vizsgált objektum. Így megállapítható az egyes geohelyszínek egyedisége.

\section{Vonzáskörzetek}

A fenti indikátorleírásokban különbözô nagyságú vonzáskörzet-sugarakról olvashatunk. A „Rálátási pontok a geotópra” indikátor esetén a $1 \mathrm{~km}$ sugarú körökön belül többféle információt is találhatunk. Fontosak a domborzati formák, hiszen olyan különbözô pontokat keresünk, amelyekrốl különbözô szögekben jól látható a célhelyszín. Ugyanakkor figyelnünk kell a vonalas elemekre is: az indikátor feltétele, hogy ezek a pontok gyalogosan, ösvényen megközelíthetők legyenek. A „Környékbeli természeti értékek" többnyire a gyújtött adathalmaz többi geotópelemét foglalja magában. A „Környékbeli épített (történeti) értékek" indikátor értékelése során kulturális értékkel bíró objektumokat keresünk a pufferen belül: pl. múzeumokat, templomokat, várakat, romokat. A „Potenciális látogatók lakóhelyének közelsége”, „Utak közelsége”, „Elérhetô pontszerú közlekedési infrastruktúra”, "Látogatóközpont közelsége”, „Turisztikai infrastruktúra”, „Szállás közelsége” és „Étkezési lehetôség közelsége” indikátorok esetén szintén az adatbázisban lévố pontszerú adatok közül a vonzáskörzetbe esố megfelelő attribútumúakat kell figyelembe vennünk.

\section{Területspecifikus változtatások az értékelési modellben}

A GAM és M-GAM modellek indikátorainak eredeti leírása néhol nem tartalmaz konkrét értékeket: pl. a „Turisztikai infrastruktúra” esetén nincs meghatározott keresési sugár. Ahhoz, hogy ezek az apró hiányok ne akadályozzák az értékelést, a mintaterülethez jól alkalmazható határokat, sugarakat építettünk az értékelési rendszerekbe: a modellek mintáját követve a „több, mint $25 \mathrm{~km} ; 25-10 \mathrm{~km} ; 10-5 \mathrm{~km} ; 5-1 \mathrm{~km}$; kevesebb, mint $1 \mathrm{~km}$ " értékekkel. A „Potenciális látogatók lakóhelyének közelsége” és „Utak közelsége” indikátorok esetében nem volt meghatározott referenciaelem. Lakóhely esetén Veszprém, Székesfehérvár vagy Budapest kerülhet szóba - azonban ennek nincs nagy jelentősége, hiszen mindhárom ugyanabba a távolságkategóriába esik. Hasonló helyzet állt elô az utak esetében is. A környék legjelentôsebb közlekedési elemei az M7-es autópálya és a 8-as fóút - de ezek is ugyanabba az értékelési kategóriába estek, így ugyanazt a pontszámot adják minden geohelyszínre. Fontos azonban hangsúlyozni, hogy ezek egyedi körülmények, más területek értékelése esetén ezeket felül kell vizsgálni.

Mivel a mintaterület viszonylag kicsi, és nem foglal magába nagy településeket, a vonzáskörzetekbe legtöbbször kevés elem esett. Ez egyszerúvé tette a munkát, viszont nagyobb, kiépített geotópok esetén, amelyek turisztikai hasznosítása aktívabb, a több objektum megnehezítette volna a számolást. 


\section{Az értékelt geotópok klaszterezése}

Az egyes indikátorok pontszámainak összege adja a geotópok GAM pontszámát (ez megszorozva a látogatók indikátorokra vonatkozó számszerúsített véleményével pedig az M-GAM pontszámát). Az értékek alapján különbözô módokon klaszterezhetjük a helyszíneket, hogy csak a legjelentôsebbek kerüljenek ábrázolásra a térképen. Jenks természetes törések módszerét használtuk a leválogatáshoz (Jenks 1963): ez minimalizálja a szórást az egyes csoportelemek

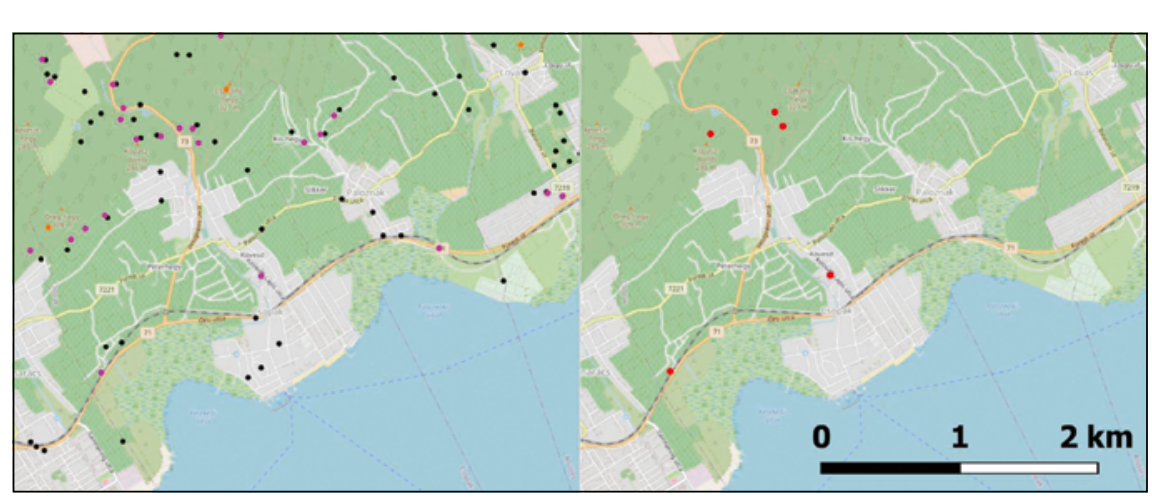

7. ábra. A bal oldali ábrán a földtani és topográfiai (fekete) térképekrôl, terepi munkával (lila) és Google-fotók segítségével (narancs) rögzitett pontok láthatók Csopak környékén. Jobb oldalon a Jenks-optimalizáció utáni helyszinek láthatók (pirossal) ugyanazon a területen (háttértérkép: OpenStreetMaps).

A 24 leválogatott és térképen megjelenített geohelyszín és M-GAM-pontszámaik, valamint az EOV-koordinátáik.

\begin{tabular}{|c|c|c|}
\hline Név & Pontszám & EOV-koordináták \\
\hline Lóczy-barlang, kôfejtô & 16.43 & 3718751,5207942 \\
\hline Felsôörs, Forrás-hegyi tanösvény & 15.26 & 3723819,5213552 \\
\hline Köcsi-tavi tanösvény & 14.74 & 3728014,5212563 \\
\hline Koloska-sziklák & 14.65 & 3719418,5210366 \\
\hline Alsóörs, Vöröskô tanösvény, amfiteátrum & 13.85 & 3726242,5211960 \\
\hline Lóczy-barlang feletti mészkôsziklák & 13.30 & 3718927,5208038 \\
\hline Csopak, Nemzeti Park Igazgatóság parkja, Pele-körút & 13.05 & 3722881,5208912 \\
\hline Csopak (Nádaskút), werfeni alapszelvény & 12.71 & 3721424,5207975 \\
\hline Miske-szikla & 12.67 & 3724535,5212423 \\
\hline Alsóörsi metariolit, alapszelvény & 12.22 & 3726532,5210462 \\
\hline Fôdolomit feltárások a Koloska-völgyben & 12.14 & 3719724,5209767 \\
\hline Sándorhegyi és Fődolomit Formációk alapszelvénye & 11.84 & 3721830,5211741 \\
\hline Miske-sziklával szemközti feltárás & 11.74 & 3724271,5212256 \\
\hline Kopasz-domb, kôfejtô orma & 11.74 & 3721653,5210155 \\
\hline Kő-hegy - Ember-szikla & 11.55 & 3726955,5217114 \\
\hline Koloska-hárs & 11.43 & 3719174,5211117 \\
\hline Nagy-kô orra & 11.31 & 3727593,5212311 \\
\hline Iszkahegyi Mészkôsziklák a Csákány-hegyi-barlangnál & 11.15 & 3722381,5210266 \\
\hline Sárkány-lik & 11.14 & 3717669,5209788 \\
\hline Király-kúti-völgy, mészkő & 10.97 & 3723285,5213027 \\
\hline Tamás-hegy, dolomitos üledékfal & 10.89 & 3719391,5207781 \\
\hline Csákány-hegyi-barlang & 10.83 & 3722295,5210421 \\
\hline Balatonalmádi, triász alapszelvény & 10.81 & 3727317,5218305 \\
\hline Balatonalmádi, P/T alapszelvény & 10.66 & 3728388,5216641 \\
\hline
\end{tabular}

során - ami a geotúratérkép készítésének is munkafázisa volt - 75 geotópot látogattunk meg és értékeltünk. A maximális pontszám 16,43 (Lóczy-barlang), míg a legalacsonyabb 7,38 lett (üledékfal Csopak mellett). Jenks módszerének segítségével ebból 24 került kiválasztásra (1. táblázat) és megjelenítésre a térképen. E helyszínek geoturisztikai hasznosítása nagyrészt már ezelôtt is aktív volt. A munka létjogosultságát és eredményességét jelzi azonban, hogy több olyan geohelyszínt sikerült beazonosítani, amelyek eddig nem rendelkeztek infrastruktúrával, pedig megfelelố tudományos értékekkel bírnak (pl.: Ember-szikla, Sárkány-lik, Csákány-hegyi-barlang, Kopasz-domb).

\section{Magyarország elsố földtani túratérképe}

A térkép tervezése az Albert (2004) által leírt alapelvek mentén kezdôdött. A hazánkban eddig nem elterjedt térképtípus szerkesztése mellett kíváncsiak voltunk arra, hogy egy szabad felhasználású geoinformatikai szoftver (esetünkben a QGIS) képes-e teljes mértékben, egy nyomtatásra szánt térkép elkészítésére.

A térképkivágat szerkesztése alapvetôen négy fố részből állt. Elsô lépésben a vektorgrafikus állományként rendelkezésünkre álló „Felsôörs és környék"' c. turistatérképet (Schwarcz 2013) helyeztük térinformatikai környezetbe: ez a térképrajzi kategóriáknak megfelelố rétegek külön-külön történô georeferálását jelentette. Ezután helyesbítettük a turistatérképi és topográfiai tematikát - egy idôben a potenciális geotópok terepi szemrevételezésével és értékelésével. A harmadik lépés a földtani tematika létrehozása volt a geológiai térképek térinformatikai feldolgozásával és a túratérkép földtani jelkulcsának létrehozásával. Végül kidolgoztuk a kész rétegek stílusát, és véglegesítettük a rétegsorrendet. Az alkalmazott munkafolyamat révén a térkép minden eleme GIS-környezetbe került, lehetôvé téve az egyszerú naprakészen tartást és 


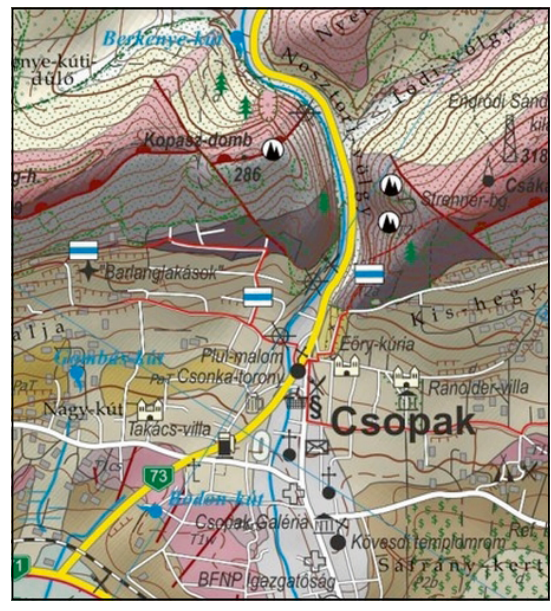

8. ábra. „Csopak és környéke geotúratérképe” egy részlete.

az esetleges digitális, adatbázis-alapú közlést. A kiadvány egyéb részeinek szerkesztése, valamint a nyomtatási elôkészítés grafikus szoftverben történt (8. ábra).

A térkép egyedi, hiszen Albert (2002) kis méretú földtani túratérkép-kivágatán kívül (amely egy geológiai túravezetô része) ilyen térkép még nem készült Magyarországon. Reményeink szerint mind a turisták, mind pedig a helyiek számára hasznosnak bizonyul a kiadvány, hiszen erôsíti a helyiek kapcsolatát a természeti környezetükkel, angol és magyar nyelven is népszerúsíti a területet, valamint a természet védelmét is igyekszik szolgálni.

\section{Irodalomjegyzék}

Albert, G. 2004. Földtudományok eredménye „kézzelfoghatóan”: a földtani túratérkép. In Geodézia és Kartográfia, 56(7), pp. 27-30

Albert, G. 2019. The changing use-cases of medium and large-scale geological maps in Hungary. Proceedings of the Int. Cartogr. Assoc. 2(4), pp. 1-8.

Albert, G. In Budai, T. - Csillag, G. - Koloszár, L. - Müller, P. - Németh, K.. 2002. Geológiai kirándulások I. - A Balaton felvidék, Balaton-felvidéki Nemzeti Park Igazgatósága, Veszprém.

Albert, G. - Pál, M. - Schwarcz, Gy. 2018. Csopak és környéke geotúratérképe. 1:30 000, Schwarcz Térkép.

Bakony-Balaton Geopark 2012. Mi a geopark? Forrás:

http://geopark.hu/home/mi-a-geopark, utolsó elérés: 2020. december 12.

Bakonyerdô Zrt. 2017. Forrás: https:// www.bakonyerdo.hu/erdogazdalkodas/ erdeszeteink/balatonfured, utolsó elérés: 2020. október 25 .
Brilha, J. 2015. Inventory and Quantitative Assessment of Geosites and Geodiversity Sites: a Review. Geoheritage, 8. kötet, pp. 119-134.

DOI: $10.1007 /$ s12371-014-0139-3

Brilha, J. - Gray, M. - Pereira, D. - Pereira, P., 2018. Geodiversity: An integrative review as a contribution to the sustainable management of the whole of nature. Environmental Science and Policy, 86. kötet, pp. 19-28.

Budai, T. - Császár, G. - Csillag, G. - Dudko, A. - Koloszár, L. - Majoros, Gy. 1999 A Balaton-felvidék földtana. Budapest, Magyar Állami Földtani Intézet.

Budai, T. - Konrád, G. 2011. Magyarország földtana (egyetemi jegyzet). Pécs, Pécsi Tudományegyetem, Természettudományi Kar.

Dowling, R. 2011. Geotourism's Global Growth. In Geoheritage, 3(1), pp. 1-13 DOI: $10.1007 / \mathrm{s} 12371-010-0024-7$

Dövényi, Z. (szerk.) 2012. A Kárpát-medence földrajza. Budapest, Akadémiai Kiadó DOI: $10.1556 / 9789630598026$

Erdélyi Fazekas J. 1943: A Balaton-felvidék geológiai és hegyszerkezeti viszonyai a Veszprémi fennsíkon és Vilonya környékén. A Magyar Kir. Földtani Intézet Évkönyve 36(3), 3-29.

Futó, J. 2013. Túrajavaslatok - A természet élménye a Balaton mellékén és a Bakonyban. Csopak, Balaton-felvidéki Nemzeti Park Igazgatóság.

Fülöp J. 1990: Magyarország geológiája Paleozoikum I. Budapest: Magyar Állami Földtani Intézet, p. 325

Grant, C. 2010. Towards a typology of visitors to geosites. In Second Global Geotourism Conference, Making Unique Landforms Understandable. Mulu, Sarawak, Malaysia.

Hose, T. A. 1995. Selling the Story of Britain's Stone. In Environmental Interpretation, 10(2), pp. 16-17.

Jenks, G. F. 1963. Generalization in statistical mapping. Annals of the Association of American Geographers, 53(1), pp $15-26$

Lai, L. - Graefe, A. 2000. Identifying Market Potential and Destination Choice Factors of Taiwanese Overseas Travelers. Journal of Hospitality \& Leisure Marketing, 6(4), pp. 45-65.

DOI: $10.1300 / \mathrm{I} 150 \mathrm{v} 06 \mathrm{n} 0405$

Magyarhoni Földtani Társulat, 2017. Geotóp Nap. Online: http://geotopnap. hu/. [Hozzáférés dátuma: 2020. december 30.].

Martin, S. 2010. Geoheritage popularisation and cartographic visualisation in the Tsanfleuron-Sanetsch area (Valais, Switzerland). Mapping Geoheritage. Géovisions, 35, pp. 15-30

MBFSZ - Magyar Bányászati és Földtani Szolgálat 2021. Magyarország földtani alapszelvényei (digitális térkép). Forrás: https://map.mbfsz.gov.hu/fdt alapszelvenyek/, utolsó elérés: 2021. január 31

Melián-González, A. - Garcia-Falcón, J 2003. Competitive Potential of Tourism in Destinations. Annals of Tourism Research, 30(3), pp. 720-740

DOI: $10.1016 / \mathrm{S} 0160-7383(03) 00047-1$
MÉM OFTH Földmérési Fôosztály 1977. T 3. Az Egységes Országos Térképrendszer 1:10 000, 1:25 000 és 1:100 000 méretarányú topográfiai térképeinek jelkulcsa. Budapest.

MNTI - Magyar Néphadsereg Térképészeti Intézet 1964. Az 1:25 000, 1:50 000 és 1:100 000 méretarányú topográfiai térképek jelkulcsa, Budapest.

Newsome, D. - Dowling, R. 2010. Geotourism The Tourism of Geology and Landscape. Oxford, Goodfellow Publishers. DOI: 10.23912/978-1-906884-09-3-21

Regolini-Bissig, G. 2010. Mapping geoheritage for interpretive purpose: definition and interdisciplinary approach Mapping Geoher itage. Institut de géographie, Géovisions, Lausanne, 35 pp. 1-13.

Reynard, E. - Coratza, P. - Regolini-Bissig, G 2009. Geomorphosites. Pfeil, München

Schwarcz, Gy. 2013. Felsôörs és környéke. Schwarcz Térkép.

Teleki G. 1939. Adatok Litér és környékének sztratigráfiájához és tektonikájához. A Magyar Kir. Földtani Intézet Évkönyve 32(1), pp. 3-60.

Tomić, N. - Božić, S. 2014. A modified Geosite Assessment Model (M-GAM) and its Application on the Lazar Canyon area (Serbia). International Journal of Environmental Research, 8(4), pp 1041-1052.

Vujičić, M. - Vasiljević, D. - Marković, S. Hose, T. - Lukić, T. - Hadžić, O. - Janićević, S. 2011. Preliminary geosite assessment model (gam) and its application on Fruška Gora mountain, potential geotourism destination of Serbia. Acta Geographica Slovenica, 51(2), pp. 361-377. DOI: $10.3986 /$ AGS51303

Zentai, L. 2015. The Effect of the Political Transition of Hungary on Map Publishing In Gartner G. - Haosheng H. Proceedings of the 1st ICA European Symposium on Cartography. Vienna, International Cartographic Association, 2015. pp 286-298.

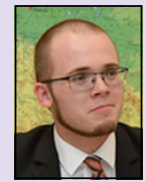

Pál Márton

doktorandusz

ELTE Földtudományi Doktori Iskola, ELTE IK Térképtudományi és Geoinformatikai Intézet marchello@map.elte.hu

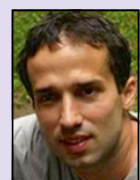

Dr. Albert
Gáspár
egyetemi docens

ELTE IK Térképtudományi és Geoinformatikai Intézet albert@ludens.elte.hu 